\title{
Model Kelembagaan Terpadu Pencegahan Kebakaran Hutan Dan Lahan Di Kabupaten Kepuluan Meranti Provinsi Riau
}

\author{
Jufri $^{1}$, Sujianto $^{2}$, Bintal Amin $^{3}$, Efriyeldi $^{3}$ \\ ${ }^{1}$ Program Doktor Ilmu Lingkungan Jl. Pattimura No. 9 Gedung I Gobah, Pekanbaru
${ }^{2}$ Fakultas Ilmu Sosial dan Politik Universitas Riau Jalan Binawidya KM 12,5 Simpang Panam
${ }^{3}$ Fakultas Perikanan dan Kelautan Universitas Riau Jalan Binawidya KM 12,5 Simpang Panam
}

Abstract: Riau is one of the most vulnerable provinces to forest and land fires in Indonesia, Meranti Islands Regency Riau Province is one of the worst places. Forest and land fires in the Meranti Islands Regency occur during the dry season. Various prevention efforts have been carried out by the government. Meranti Islands Regency 60\% is this peat area which causes opportunities for forest and land fires. This study analyzes: 1) the causes of forest and land fires in the Meranti Islands Regency, 2) the impact of forest and land fires on ecology, social and economy, 3) local wisdom owned by communities who are able to protect forests and land, 4) find prevention models forest and land fires based on integrated and effective institutions. This study uses a survey method. The data obtained were analyzed descriptively by using the mix methods approach by combining two forms of quantitative and qualitative approaches. Data analysis uses statistics with Pearson Correlation test and SWOT analysis. The results of the analysis concluded that the most dominant variables causing forest and land fires in the Meranti Islands Regency were socio-cultural conditions (69.06\%), this also has an impact on socio-cultural factors (62.68\%). local wisdom in the community is one effort that can prevent forest and land fires, is the tradition of sago planting and bele kampung tradition. The results of the SWOT analysis produce an alternative $S$-O (StrenghtsOpportunity) strategy in cell 1 position with the power to take advantage of opportunities. The model for preventing forest and land fires based on integrated institutions is: 1) government, 2) research institutions are universities, 3) community institutions such as the Fire Concern Society (MPA).

Key words: forest and land fires, local wisdom, institutional model of Meranti Islands Regency

Kebakaran hutan dan lahan di Indonesia pada saat ini menjadi sorotan tajam dan topik yang hangat di tengah-tengah masyarakat dan berbagai pihak termasuk media masa, karena polusi asap yang ditimbulkan akibat kebakaran hutan dan lahan telah menjadi isu regional dan internasional (Aiken, 2004 ; Jones, 2006, dan Litta, 2012). Provinsi Riau sebagai salah satu daerah yang hampir setiap tahun berpotensi terjadinya kebakaran hutan dan lahan. Bencana asap yang telah terjadi di Provinsi Riau akibat kebakaran hutan dan lahan berdampak pada seluruh aspek kehidupan. Menurut Suwondo, et al. (2015), dampak terjadinya kebakaran hutan dan lahan dapat dikategorikan menjadi empat yaitu : 1) dampak terhadap ekologis dan kerusakan lingkungan, 2) dampak terhadap sosial, budaya, dan ekonomi, 3) dampak terhadap hubungan antar negara, 4) dampak terhadap perhubungan dan pariwisata.
Lahan gambut dalam kondisi alamiah tidak mudah terbakar. Lahan gambut menjadi mudah terbakar karena adanya faktor pemicu seperti penebangan liar, pembukaan lahan untuk pertanian, industri dan pemukiman serta pertambangan (Zubaidah et al., 2005 ; Masganti et al., 2014). Kebakaran yang terjadi di Provinsi Riau sebagian besar berada pada kawasan hutan dan lahan gambut salah satunya berada pada kawasan hutan di Kabupaten Kepulauan Meranti. Tanah gambut yang terdapat di Kabupaten Kepulauan Meranti merupakan jenis tanah gambut trofik yang dibentuk oleh bahanbahan sisa tanaman purba yang berlapis-lapis hingga mencapai ketebalan lebih dari $30 \mathrm{~cm}$. Bahan organik yang membentuk tanah gambut pada umumnya memiliki ketebalan di atas 75 $\mathrm{cm}$, bahkan di beberapa lokasi ketebalannya lebih dari 3 m (RTRW Meranti-Bapeda, 20112013). 
Suratmo, et al. (2003), menyatakan aspek pencegahan lebih penting sebagai tindak awal dan jauh lebih baik dari pada melakukan pemadaman, apalagi proses pemadaman api dan rehabilitasi akan membutuhkan biaya yang besar dan waktu yang sangat lama. Kegiatan pencegahan kebakaran hutan menjadi efektif dan efisien jika dilakukan bersama dengan masyarakat. Hal ini didasari karena permasalahan kebakaran hutan bukan hanya permasalahan teknis tetapi juga permasalahan pengelolaan sumber api"yang disebabkan oleh kegiatan-kegiatan penggunaan api baik karena alasan ekonomi dan kepraktisan (Purnasari, 2011). Kelembagaan pencegahan kebakaran hutan dan lahan selama ini sudah ada baik di tingkat nasional, tingkat provinsi, tingkat kabupaten/kota dan tingkat kecamatan, tetapi belum berfungsi dengan semestinya dan pelaksanaannya belum efisien dan efektif sehingga kebakaran hutan dan lahan tetap terjadi. Berdasarkan fenomena tersebut maka perlu dilakukan penelitian tentang model pencegahan kebakaran hutan dan lahan berbasis pada kelembagaan terpadu dan komprehensif yang efektif dan efisien di Kabupaten Kepulauan Meranti Provinsi Riau.

\section{BAHAN DAN METODE}

Penelitian ini menggunakan pendekatan dengan metode survei. Metode survei adalah metode yang menggunakan kuesioner sebagai instrumen untuk mengumpulkan data. Penelitian survei memerlukan responden dalam jumlah yang cukup, agar validitas temuan bisa dicapai dengan baik (Irawan, 2000). Selanjutnya data yang diperoleh akan dianalisis dengan menggunakan dua metode ( $m i x$ methods). Mix Methods adalah suatu langkah penelitian dengan menggabungkan dua bentuk pendekatan penelitian yaitu kuantitatif dan kualitatif (Creswell, 2010). Menurut Sugiyono (2011), mix methods adalah metode penelitian dengan mengkombinasikan antara dua metode penelitian sekaligus, kuantitatif dan kualitatif dalam suatu kegiatan penelitian sehingga akan diperoleh data yang lebih komprehensif, valid, realibel dan objektif. Meskipun ada perbedaan asumsi dan prinsip-prinsip dasar penelitian kuantitatif dan kualitatif, tetapi ada ahli yang berpandangan pragmatis lebih melihat penerapan antara kedua penelitian tersebut (Sukmadinata, 2008).

\section{HASIL}

Hasil uji Pearson Correlation bertujuan untuk mengetahui indikator dari faktor sosial budaya, faktor ekonomi serta faktor kondisi cuaca dan iklim/ekologi yang diduga sebagai penyebab terjadinya kebakaran hutan dan lahan di Kabupaten Kepuluan Meranti.

Tabel 1. Hasil Rata-Rata Asymp. Sig Uji Pearson correlation Penyebab Terjadinya Kebakaran Hutan dan Lahan pada 8 Desa di 5 Wilayah Kecamatan Kabupaten Kepuluan Meranti

\begin{tabular}{|c|c|c|c|c|c|c|c|c|c|c|}
\hline \multirow{3}{*}{ NO } & \multirow{3}{*}{ Indikator dari } & \multicolumn{8}{|c|}{ Sig } & \multirow{3}{*}{$\begin{array}{l}\text { Rata- } \\
\text { Rata }\end{array}$} \\
\hline & & \multicolumn{8}{|c|}{ nama Desa } & \\
\hline & & \begin{tabular}{|l|} 
Bagan Melibur \\
\end{tabular} & Mekar sari & Mengkirau & Mengkopot & P. Balai & R. Dungun & Kundur & Alahair & \\
\hline A & Faktor Sosial Budaya & 0,000 & 0,000 & 0,000 & 0,000 & 0,003 & 0,000 & 0,000 & 0,000 & 0,000 \\
\hline 1 & $\begin{array}{l}\text { Penggunaan api dalam } \\
\text { kegiatan persiapan lahan }\end{array}$ & 0.003 & 0,006 & 0,001 & 0,279 & 0,015 & 0,000 & 0,000 & 0,048 & 0,049 \\
\hline 2 & $\begin{array}{l}\text { Adanya kekecewaan } \\
\text { terhadap sistem pengelolaan } \\
\text { hutan }\end{array}$ & 0,005 & 0,043 & 0,001 & 0,156 & 0,003 & 0,104 & 0,002 & 0,000 & 0,039 \\
\hline 3 & $\begin{array}{l}\text { Penmbalakkan liar atau ilegal } \\
\text { logging dan perambahan hutan }\end{array}$ & 0,011 & 0,021 & 0,000 & 0,004 & 0,177 & 0,000 & 0,000 & 0,000 & 0,027 \\
\hline 4 & $\begin{array}{l}\text { Pembukaannlahan oleh para } \\
\text { pemegang HPH (hak } \\
\text { pengusahaan hutan) }\end{array}$ & 0,125 & 0,026 & 0,000 & 0,006 & 0,043 & 0,004 & 0,000 & 0,000 & 0,026 \\
\hline 5 & $\begin{array}{l}\text { Konflik antara pemodal } \\
\text { dengan penduduk asli }\end{array}$ & 0,031 & 0,001 & 0,000 & 0,007 & 0,144 & 0,000 & 0,000 & 0,011 & 0,023 \\
\hline 6 & $\begin{array}{l}\text { Sistem perladangan tradisional } \\
\text { dari penduduk setempat yang } \\
\text { berpindah-pindah }\end{array}$ & 0,001 & 0,004 & 0,000 & 0,000 & 0,035 & 0,033 & 0,001 & 0,000 & 0,014 \\
\hline B & Faktor Ekonomi & $0, \mathrm{OOO}$ & 0,112 & 0,065 & 0,009 & 0,013 & 0,000 & 0,173 & 0,000 & 0,047 \\
\hline 1 & Angka Kemiskinan & 0,000 & 0,141 & 0,264 & 0,362 & 0,001 & 0,002 & 0,414 & $0, \mathrm{OOO}$ & 0,150 \\
\hline 2 & $\begin{array}{l}\text { Minimnya lapangan pekerjaan } \\
\text { dan usaha }\end{array}$ & 0,001 & 0,355 & 0,055 & 0,016 & 0,387 & 0,001 & 0,136 & 0,000 & 0,119 \\
\hline 3 & $\begin{array}{l}\text { Infrastruktur pedesaan yang } \\
\text { buruk }\end{array}$ & 0,001 & 0,257 & 0,096 & 0,095 & 0,014 & 0,000 & 0,149 & 0,000 & 0,077 \\
\hline C & Faktor Kondisi Cuaca & 0,000 & 0,000 & 0,000 & 0,000 & 0,000 & 0,001 & 0,005 & 0,000 & 0,001 \\
\hline 1 & Suhu & 0,025 & 0,001 & 0,338 & 0,047 & 0,016 & 0,015 & 0,036 & 0,000 & 0,059 \\
\hline 2 & Tekanan Udara & 0,000 & 0,000 & 0,001 & 0,046 & 0,000 & 0,053 & 0,013 & 0,000 & 0,014 \\
\hline 3 & Angin & 0,000 & 0,000 & 0,123 & 0,111 & 0,003 & 0,037 & 0,029 & 0,000 & 0,038 \\
\hline 4 & Kelembaban udara dan awan & 0,000 & $\mathrm{O}, \mathrm{OOO}$ & 0,001 & 0,003 & 0,000 & 0,114 & 0,089 & 0,000 & 0,029 \\
\hline 5 & Curah hujan(presipitasi) & 0,000 & 0,000 & 0,008 & 0,022 & 0,001 & 0,004 & 0,265 & 0,000 & 0,039 \\
\hline
\end{tabular}


Tabel 2. Hasil Rata-Rata Uji Pearson correlation Penyebab dari Terjadinya Kebakaran Hutan dan Lahan.

\begin{tabular}{|c|c|c|c|c|c|c|c|c|}
\hline \multicolumn{9}{|c|}{ Uji Pearson Correlation ( \%) } \\
\hline \multicolumn{9}{|c|}{ Nama Desa } \\
\hline Bagan Melibur & Mekar sari & Mengkiaru & Mengkopot & P. Balai & R. Dungun & Kundur & Alahair & Rata-Rata \\
\hline 58,30 & 58,90 & 85,40 & 70,80 & 59,30 & 67,20 & 84,60 & 68,00 & 69,06 \\
\hline 39,00 & 28,10 & 44,00 & 5,90 & 35,00 & 50,90 & 58,90 & 13,00 & 34,35 \\
\hline 36,10 & 28,60 & 42,70 & 10,02 & 58,40 & 18,10 & 51,50 & 42,70 & 36,02 \\
\hline 32,50 & 35,50 & 65,10 & 47,30 & 21,90 & 72,10 & 69,50 & 45,10 & 48,63 \\
\hline 16,50 & 18,40 & 48,60 & 45,00 & 39,30 & 36,80 & 64,70 & 63,00 & 41,54 \\
\hline 26,60 & 52,50 & 47,10 & 44,80 & 25,00 & 55,70 & 74,70 & 29,10 & 44,44 \\
\hline 42,10 & 32,50 & 50,20 & 56,80 & 41,40 & 26,20 & 54,60 & 60,90 & 45,59 \\
\hline 61,00 & 6,70 & 21,70 & 42,80 & 49,70 & 53,00 & 17,80 & 50,60 & 37,91 \\
\hline 47,20 & 20,10 & 9,20 & 6,70 & 65,60 & 31,70 & 4,20 & 38,40 & 27,89 \\
\hline 42,70 & 7,10 & 22,90 & 39,10 & 6,90 & 44,40 & 20,80 & 37,10 & 27,63 \\
\hline 44,44 & 9,10 & 18,80 & 34,60 & 47,60 & 54,40 & 19,70 & 46,60 & 33,16 \\
\hline 81,20 & 91,40 & 50,50 & 60,20 & 71,70 & 42,00 & 46,00 & 66,40 & 63,68 \\
\hline 28,20 & 53,00 & $6,40 \%$ & 29,40 & 47,20 & 30,70 & 29,50 & 36,50 & 32,61 \\
\hline 57,60 & 72,10 & $42,90 \%$ & 31,40 & 69,00 & 23,10 & 40,60 & 53,70 & 48,80 \\
\hline 52,50 & 83,20 & $11,00 \%$ & 2,30 & 58,50 & 25,40 & 34,90 & 52,80 & 40,08 \\
\hline 62,10 & 81,20 & $45,10 \%$ & 34,60 & 58,50 & 17,40 & 25,20 & 59,10 & 49,53 \\
\hline 75,80 & 64,70 & $34,00 \%$ & 36,90 & 58,50 & 37,30 & 11,90 & 53,40 & 45,57 \\
\hline
\end{tabular}

Dari Tabel 1 dan 2 dapat dijelaskan uji signifikasi dengan menggunakan Rata-Rata hasil Uji Pearson Correlation untuk masingmasing indikator dari faktor sosial budaya, faktor ekonomi serta faktor kondisi cuaca dan iklim/ekologi sebagai penyebab dari terjadinya kebakaran hutan dan lahan pada 8 desa di 5 wilayah Kecamatan Kabupaten Kepuluan Meranti, dengan penjabaran sebagai berikut:

Setelah dilakukan rata-rata terhadap hasil uji Pearson Correlation (Tabel 1 dan 2), untuk masing-masing indikator dari faktor sosial budaya dan kondisi cuaca penyebab terjadinya kebakaran hutan dan lahan pada 8 desa di 5 wilayah Kecamatan Kabupaten Kepuluan Meranti, maka didapatkan hasil sebagai berikut: ada hubungan faktor sosial budaya dan kondisi cuaca dengan penyebab terjadinya kebakaran hutan dan lahan, hal ini dibuktikan dengan hasil rata-rata uji Pearson Corralation yang nilai Asymp. Sig atau $\mathrm{p}_{\text {-value }}$ sebesar 0,000 dan 0,001 nilai tersebut $\leq 0,05$ atau ( $\mathrm{p}_{\text {-value }} 0,000$ dan $0,001 \leq$ alpha 0,05$)$, sehingga dapat disimpulkan bahwa faktor sosial budaya dan kondisi cuaca memiliki hubungan dengan terjadinya kebakaran hutan dan lahan atau faktor sosial budaya dan kondisi cuaca penyebab dari terjadinya kebakaran hutan dan lahan. Secara persentase rata-rata faktor sosial budaya dan kondisi cuaca terhadap terjadinya kebakaran hutan dan lahan adalah hanya sebesar $69,06 \%$ dan $63,68 \%$.

Faktor ekonomi ada hubungan dengan penyebab terjadinya kebakaran hutan dan lahan dibuktikan dengan hasil rata-rata uji Pearson Correlation yang menunjukkan nilai Asymp. Sig atau $\mathrm{p}_{\text {-value }}$ sebesar 0,047 nilai tersebut $\leq$ 0,05 atau ( $\mathrm{p}_{\text {-value }} 0,047 \leq$ alpha 0,05 ) sehingga dapat disimpulkan bahwa faktor ekonomi memiliki hubungan dengan terjadinya kebakaran hutan dan lahan. Secara persentase rata-rata faktor ekonomi terhadap terjadinya kebakaran hutan dan lahan adalah sebesar $37,91 \%$. Tetapi secara sub indikator faktor ekonomi tidak memiliki hubungan dengan penyebab terjadinya kebakaran hutan dan lahan.

Hasil pengujian uji Pearson Correlation adalah untuk melihat masing-masing indikator dari faktor sosial budaya, faktor ekologis dan kerusakan lingkungan serta faktor ekonomi yang terkena dampak dari terjadinya kebakaran hutan dan lahan di Kabupaten Kepuluan Meranti. 
Tabel 3. Hasil Rata-Rata Asymp. Sig Uji Pearson Correlation Dampak dari Terjadinya Kebakaran Hutan dan Lahan pada 8 Desa di 5 Wilayah Kecamatan Kabupaten Kepuluan Meranti

\begin{tabular}{|c|c|c|c|c|c|c|c|c|c|c|}
\hline \multirow{3}{*}{ NO } & \multirow{3}{*}{ Indikator dari } & \multicolumn{8}{|c|}{$\mathrm{Sig}$} & \multirow{3}{*}{ Rata-Rata } \\
\hline & & \multicolumn{8}{|c|}{ nama Desa } & \\
\hline & & Bagan Melibur & Mekar sari & Mengkirau & Mengkopot & P. Balai & R. Dungun & Kundur & Alahair & \\
\hline$A$ & Faktor Sosial Budaya & 0,000 & 0,029 & 0,000 & 0,000 & 0,000 & 0,000 & 0,000 & 0,000 & 0,006 \\
\hline 1 & $\begin{array}{l}\text { Terganggunya aktivitas } \\
\text { sehari-hari }\end{array}$ & 0,001 & 0,04 & 0,046 & 0,000 & 0,107 & 0,000 & 0,039 & 0,000 & 0,039 \\
\hline 2 & $\begin{array}{l}\text { Meningkatnya } \\
\text { pengangguran }\end{array}$ & 0,000 & 0,487 & 0,037 & 0,001 & 0,088 & 0,000 & 0,004 & 0,000 & 0,109 \\
\hline 3 & Peningkatan jumlah hama & 0,000 & 0,012 & 0,016 & 0,007 & 0,045 & 0,000 & 0,005 & 0,000 & 0,040 \\
\hline 4 & Terganggunya Kesehatan & 0,001 & 0,026 & 0,177 & 0,018 & 0,004 & 0,000 & 0,009 & 0,000 & 0,045 \\
\hline 5 & Produktivitas menurun & 0,000 & 0,243 & 0,003 & 0,000 & 0,226 & 0,017 & 0,000 & 0,000 & 0,082 \\
\hline $\mathrm{B}$ & Faktor Ekologis & 00 & 0,000 & 0,000 & 0,028 & 0,000 & 0,001 & 0,000 & 0,000 & 0,006 \\
\hline 1 & Hilangnya sejumlah spesies & 0,139 & 0,041 & 0,000 & 0,432 & 0,011 & 0,132 & 0,107 & 0,000 & 0,142 \\
\hline 2 & Ancaman Erosi & 0,103 & 0,063 & 0,004 & 0,004 & 0,001 & 0,001 & 0,009 & 0,000 & 0,026 \\
\hline 3 & $\begin{array}{l}\text { Perubahan fungsi } \\
\text { pemanfaatan dan } \\
\text { peruntukan lahan }\end{array}$ & 0,000 & 0,000 & 0,004 & 0,001 & 0.042 & 0,016 & 0,000 & 0,000 & 0,012 \\
\hline 4 & Penurunan Kualitas Air & 0,000 & 0,028 & 0,036 & 0,028 & 0,003 & 0,000 & 0,000 & 0,000 & 0,020 \\
\hline 5 & Segmentasi di aliran sungai & 0,000 & 0,005 & 0,000 & 0,081 & 0,149 & 0,028 & 0,002 & 0,000 & 0,033 \\
\hline $\mathrm{C}$ & Faktor Ekonomi & 0,000 & 0,000 & 0,000 & 0,003 & 0,021 & 0,001 & 0,000 & 0,000 & 0,004 \\
\hline 1 & $\begin{array}{l}\text { Hilangnya sejumlah mata } \\
\text { pencaharian masyarakat di } \\
\text { sekitar hutan }\end{array}$ & 0,001 & 0,001 & 0,000 & 0,161 & 0,013 & 0,000 & 0,001 & 0,000 & 0,025 \\
\hline 2 & $\begin{array}{l}\text { Terganggunya transportasi } \\
\text { darat, laut/sungai dan udara }\end{array}$ & 0,000 & 0,000 & 0,000 & 0,013 & 0,108 & 0,044 & 0,002 & 0,000 & 0,024 \\
\hline
\end{tabular}

Tabel 4. Hasil Rata-Rata Uji Pearson Correlation Dampak dari Terjadinya Kebakaran Hutan dan Lahan

\begin{tabular}{|c|c|c|c|c|c|c|c|c|}
\hline \multicolumn{9}{|c|}{ Uji Pearson Correlation (\%) } \\
\hline \multicolumn{9}{|c|}{ Nama Desa } \\
\hline Bagan Melibur & Mekar sari & Mengkirau & Mengkopot & P. Balai & R. Dungun & Kundur & Alahair & Rata-Rata \\
\hline 71,50 & 35,00 & 47,00 & 74,30 & 69,00 & 78,00 & 62,01 & 64,50 & 62,68 \\
\hline 41,10 & 32,40 & 22,80 & 59,80 & 29,10 & 50,70 & 32,80 & 60,90 & 41,20 \\
\hline 49,30 & 1,60 & 25,60 & 56,40 & 31,50 & 63,70 & 32,50 & 49,00 & 38,70 \\
\hline 43,80 & 22,10 & 30,40 & 44,60 & 36,80 & 66,50 & 29,90 & 53,00 & 40,89 \\
\hline 42,80 & 0,53 & 13,40 & 39,00 & 40,10 & 63,30 & 42,80 & 53,90 & 36,92 \\
\hline 50,00 & 13,20 & 37,80 & 64,50 & 17,80 & 30,10 & 37,70 & 56,80 & 40,99 \\
\hline 70,10 & 69,80 & 62,10 & 3,52 & 75,40 & 44,90 & 74,20 & 64,90 & 58,12 \\
\hline 15,70 & 32,20 & 48,40 & 3,30 & 28,40 & 16,10 & 23,40 & 42,40 & 24,90 \\
\hline 18,20 & 28,60 & 36,80 & 47,50 & 63,60 & 44,00 & 42,80 & 49,70 & 41,40 \\
\hline 55,00 & 61,80 & 37,40 & 53,30 & 35,50 & 31,00 & 57,60 & 46,90 & 42,14 \\
\hline 45,60 & 35,10 & 25,60 & 35,30 & 42,80 & 45,30 & 37,40 & 55,70 & 42,85 \\
\hline 54,60 & 46,00 & 47,20 & 26,20 & 24,50 & 27,10 & 52,00 & 67,00 & 43,08 \\
\hline 48,80 & 68,20 & 69,30 & 49,60 & 46,00 & 43,40 & 63,30 & 41,70 & 53,79 \\
\hline 16,40 & 53,30 & 56,90 & 18,70 & 49,60 & 52,60 & 53,00 & 36,90 & 42,18 \\
\hline 29,60 & 63,70 & 62,10 & 40,60 & 28,90 & 24,40 & 50,00 & 41,30 & 42,58 \\
\hline
\end{tabular}


Dari Tabel 3 dan 4 dapat dijelaskan uji signifikasi dengan menggunakan rata-rata hasil Uji Pearson Correlation untuk masing-masing indikator dari faktor sosial budaya, faktor ekologis dan kerusakan lingkungan serta faktor ekonomi yang terkena dampak dari terjadinya kebakaran hutan dan lahan pada 8 desa di 5 wilayah Kecamatan kabupaten Kepulauan Meranti, dengan penjabaran sebagai berikut:

Kebakaran hutan dan lahan memiliki hubungan dampak terhadap faktor sosial budaya, faktor ekologis dan kerusakan lingkungan dan ekonomi dibuktikan dengan hasil rata-rata uji Pearson Correlation yang menunjukkan nilai Asymp. Sig atau p-value sebesar 0,006 dan 0,004 nilai tersebut $\leq 0,05$ atau ( $\mathrm{p}_{\text {-value }} 0,006$ dan $0,004 \leq$ alpha 0,05 ) sehingga dapat disimpulkan bahwa terjadinya kebakaran hutan dan lahan memiliki hubungan dampak terhadap faktor sosial budaya, ekologis dan kerusakan lingkungan dan ekonomi. Secara persentase rata-rata dampak dari terjadinya kebakaran hutan dan lahan terhadap faktor sosial budaya adalah sebesar $62,68 \%, 58,12 \%$ dan $53,79 \%$.

\section{Peran Sagu Dalam sosial budaya, ekonomi dan lingkungan}

Sagu di Indonesia tumbuh dalam bentuk hamparan hutan yang kurang terpelihara sebagai mana mestinya. Adapun peran sagu sebagai berikut :

a. Aspek sosial budaya, Budidaya masyarakat lokal di Kabupaten Kepuluan Meranti adalah menanam sagu merupakan tanaman kearifan lokal yang sudah menjadi budidaya masyarakat sejak zaman Kerajaan Siak.

b. Aspek ekonomi, Selain unggul dari sifat fungsionalnya sebagai penyangga ketahanan pangan, sagu juga memiliki nilai ekonomi cukup baik. c. Aspek lingkungan, tanaman sagu dapat menjaga tata air di sekitarnya. Beberapa fakta di lapangan menunjukkan bahwa banyak di daerah pedesaan.

\section{Peran Tradisi Bele Kampung Terhadap Aspek Sosial Budaya, Ekologi dan Ekonomi.}

Kehidupan sederhana masyarakat Desa Dedap membuat kebersamaan dan keharmonisan dalam pelaksanaan tradisi bele kampung mencerminkan betapa besar keinginan masyarakat Desa Dedap Kecamatan Tasik Putripuyu untuk memperhatikan lingkungan yang termuat dalam nilai-nilai kearifan lokal yang menghargai keseimbangan antara manusia dan lingkungan demi kepentingan jangka panjang.

\section{Model Pencegahan Kebakaran Hutan dan Lahan yang Berbasis Berbasis pada Kelembagaan Terpadu dan Komprehensif (Analisis SWOT)}

Perumusan model pencegahan kebakaran hutan dan lahan menggunakan analisis SWOT yang merupakan salah satu analisis yang digunakan untuk merumuskan suatu strategi pada suatu bidang pengembangan. Analisis ini terdiri dari 4 elemen dasar yaitu : kekuatan (strenghts), kelemahan (weakness), peluang (opportunity) dan ancaman (threats). Keempat elemen tersebut berasal dari 2 faktor utama yaitu : faktor internal (kekuatan dan kelemahan) dan eksternal (peluang dan ancaman).

\section{Matriks Internal Factor Analysis Strategy (IFAS)}

Matrik IFAS merupakan faktor-faktor strategi yang berasal dari dalam sistem yaitu faktor kekuatan dan kelemahan. Maka dapat diklasifikasikan faktor kekuatan dan kelemahan beserta nilai skor seperti pada Tabel 5 . 
Tabel 5. Matrik Internal Faktor Analisis Strategi

\begin{tabular}{|c|c|c|c|c|c|c|c|}
\hline No & Kekuatan (strenghts): & Peringkat & $\begin{array}{l}\text { Konstanta } \\
\quad(\mathrm{K})\end{array}$ & RxK & Bobot & Rating & Skor \\
\hline 1 & Kearifan lokal (budaya menanam sagu) & 4 & 7 & 28 & 0,143 & 3 & 0,43 \\
\hline 2 & Adanya tradisi "bele kampong" & 1 & 7 & 7 & 0,036 & 2 & 0,07 \\
\hline 3 & Adanya MPA & 7 & 7 & 49 & 0,250 & 4 & 1,00 \\
\hline 4 & $\begin{array}{l}\text { Meningkatnya kesadaran masyarakat dalam } \\
\text { pencegahan kebakaran hutan }\end{array}$ & 6 & 7 & 42 & 0,214 & 4 & 0,86 \\
\hline 5 & $\begin{array}{l}\text { Adanya sistem early warning kebakaran hutan } \\
\text { dan lahan }\end{array}$ & 2 & 7 & 14 & 0,071 & 2 & 0,14 \\
\hline 6 & $\begin{array}{l}\text { Adanya UU, Pergub, dan Perbup tentang } \\
\text { penanggulangan kebakaran hutan }\end{array}$ & 5 & 7 & 35 & 0,179 & 4 & 0,71 \\
\hline 7 & $\begin{array}{l}\text { Adanya sosialisasi berkala terhadap bahaya } \\
\text { kebakaran hutan dan lahan }\end{array}$ & 3 & 7 & 21 & 0,107 & 3 & 0,32 \\
\hline Total & & & & 196 & 1,00 & & 3,54 \\
\hline 1 & $\begin{array}{l}\text { Kelemahan (Weakness): } \\
\text { Masyarakat masih membakar lahan untuk } \\
\text { persiapan lahan }\end{array}$ & 8 & 13 & 104 & 0,088 & 3 & 0,26 \\
\hline 2 & $\begin{array}{l}\text { Sistem pengelolaan hutan masih belum } \\
\text { optimal }\end{array}$ & 4 & 13 & 52 & 0,044 & 2 & 0,09 \\
\hline 3 & $\begin{array}{l}\text { Masih adanya pembalakan liar atau illegal } \\
\text { loging }\end{array}$ & 2 & 13 & 26 & 0,022 & 1 & 0,02 \\
\hline 4 & Masih adanya perambahan hutan & 5 & 13 & 65 & 0,055 & 3 & 0,16 \\
\hline 5 & Adanya pembukaan lahan baru oleh HPH & 1 & 13 & 13 & 0,011 & 1 & 0,01 \\
\hline 6 & $\begin{array}{l}\text { Adanya konflik sosial antara pemilik modal } \\
\text { dengan penduduk asli }\end{array}$ & 3 & 13 & 39 & 0,033 & 2 & 0,07 \\
\hline 7 & Belum optimalnya fungsi MPA & 13 & 13 & 169 & 0,143 & 4 & 0,57 \\
\hline 8 & $\begin{array}{l}\text { Anggaran dan sarana prasarana MPA belum } \\
\text { memadai }\end{array}$ & 12 & 13 & 156 & 0,132 & 3 & 0,40 \\
\hline 9 & $\begin{array}{l}\text { Angggota } \\
\text { memadai }\end{array}$ MPA belum keahlian yang & 11 & 13 & 143 & 0,121 & 3 & 0,36 \\
\hline 10 & Birokrasi pemerintahan yang berbelit belit & 9 & 13 & 117 & 0,099 & 3 & 0,30 \\
\hline 11 & Lemahnya penegakan hukum & 7 & 13 & 91 & 0,077 & 3 & 0,23 \\
\hline 12 & $\begin{array}{l}\text { Belum ditetapkannya RTRW Kabupaten } \\
\text { Kepulauan Meranti }\end{array}$ & 10 & 13 & 130 & 0,110 & 3 & 0,33 \\
\hline 13 & $\begin{array}{l}\text { Belum adanya model pencegahan kebakaran } \\
\text { hutan dan lahan terpadu }\end{array}$ & 6 & 13 & 78 & 0,066 & 3 & 0,20 \\
\hline \multicolumn{4}{|l|}{ Total } & 1183 & 1,000 & & 2,38 \\
\hline \multicolumn{4}{|c|}{ Strenght +Weakness } & & & & 5,92 \\
\hline \multicolumn{7}{|c|}{ Strenght-Weakness } & 1,15 \\
\hline
\end{tabular}

Matriks External Factor Analysis Strategy (EFAS)

Matrik EFAS merupakan faktor-faktor strategi yang berasal dari luar sistem yaitu faktor peluang dan ancaman. Maka dapat diklasifikasikan faktor peluang dan ancaman beserta nilai skor seperti pada Tabel 6 . 
Tabel 6. Matrik Eksternal Faktor Analisis

\begin{tabular}{|c|c|c|c|c|c|c|c|}
\hline No & Peluang (Opportunities): & Peringkat & $\begin{array}{c}\text { Konstanta } \\
(\mathrm{K})\end{array}$ & $\mathrm{RxK}$ & Bobot & Rating & Skor \\
\hline 1 & Restorasi Gambut & 5 & 5 & 25 & 0,33 & 4 & 1,33 \\
\hline \multirow[t]{2}{*}{2} & Masuk dalam kawasan Lokasi & 4 & 5 & 20 & 0,27 & 4 & 1,07 \\
\hline & $\begin{array}{l}\text { Prioritas Penangan } \quad \text { Bencana } \\
\text { Kebakaran Hutan (Peraturan BNPP } \\
\text { No.2 Tahun 2015) }\end{array}$ & & & & & & \\
\hline 3 & $\begin{array}{l}\text { Adanya penelitian dan kajian yang } \\
\text { berkaitan dengan kebakaran hutan }\end{array}$ & 1 & 5 & 5 & 0,07 & 3 & 0,20 \\
\hline 4 & $\begin{array}{l}\text { Dijadikannya kebakaran hutan dan } \\
\text { lahan sebagai bencana nasional }\end{array}$ & 2 & 5 & 10 & 0,13 & 4 & 0,53 \\
\hline \multirow[t]{3}{*}{5} & $\begin{array}{l}\text { Keterlibatan perusahaan-perusahan } \\
\text { swasta yang ada di Meranti (NSP dan } \\
\text { RAPP) }\end{array}$ & 3 & 5 & 15 & 0,20 & 3 & 0,60 \\
\hline & TOTAL & & & 75 & $\mathbf{1 , 0 0}$ & & 3,73 \\
\hline & Ancaman (threats): & & & & & & \\
\hline 1 & $\begin{array}{l}\text { Kondisi cuaca dan iklim yang tidak } \\
\text { menentu }\end{array}$ & 1 & 10 & 10 & 0,02 & 1 & 0,02 \\
\hline 2 & $\begin{array}{l}\text { Hilangnya mata pencaharian } \\
\text { masyarakat disekitar hutan }\end{array}$ & 7 & 10 & 70 & 0,13 & 2 & 0,25 \\
\hline 3 & $\begin{array}{l}\text { Terganggunya kesehatan dan aktifitas } \\
\text { sekitar hutan }\end{array}$ & 6 & 10 & 60 & 0,11 & 2 & 0,22 \\
\hline 4 & Menurunnya produktivitas tanaman & 2 & 10 & 20 & 0,04 & 1 & 0,04 \\
\hline 5 & Rusak ekosistem hutan & 5 & 10 & 50 & 0,09 & 3 & 0,27 \\
\hline 6 & Erosi & 4 & 10 & 40 & 0,07 & 2 & 0,15 \\
\hline 7 & $\begin{array}{l}\text { Perubahan fungsi pemanfaatan dan } \\
\text { peruntukan lahan }\end{array}$ & 8 & 10 & 80 & 0,15 & 3 & 0,44 \\
\hline 8 & Terganggunya transportasi & 3 & 10 & 30 & 0,05 & 1 & 0,05 \\
\hline 9 & $\begin{array}{l}\text { Kondisi geografis yang menyulitkan } \\
\text { ketika pemadaman }\end{array}$ & 10 & 10 & 100 & 0,18 & 4 & 0,73 \\
\hline \multirow[t]{4}{*}{10} & $\begin{array}{l}\text { Meningkatnya kebutuhan msyarakat } \\
\text { akan lahan pertanian/perkebunan }\end{array}$ & 9 & 10 & 90 & 0,16 & 3 & 0,49 \\
\hline & TOTAL & & & 550 & 1 & & 2,65 \\
\hline & Opportunities + Threats & & & & & & 6,38 \\
\hline & Opportunities - Threats & & & & & & 1,08 \\
\hline
\end{tabular}

\section{Diagram Cartesius IFAS dan EFAS}

Matrik Grand Strategy didapatkan dari selisih jumlah faktor internal dan selisih jumlah faktor eksternal yang telah teridentifikasi. Berdasarkan selisih jumlah faktor internal (antara kekuatan dan kelemahan atau $3.54-2.38=1.15$.) dan selisih total nilai pengaruh unsur eksternal (peluang dan ancaman atau $3.73-2.65=1.08$ ) pada Gambar 10.

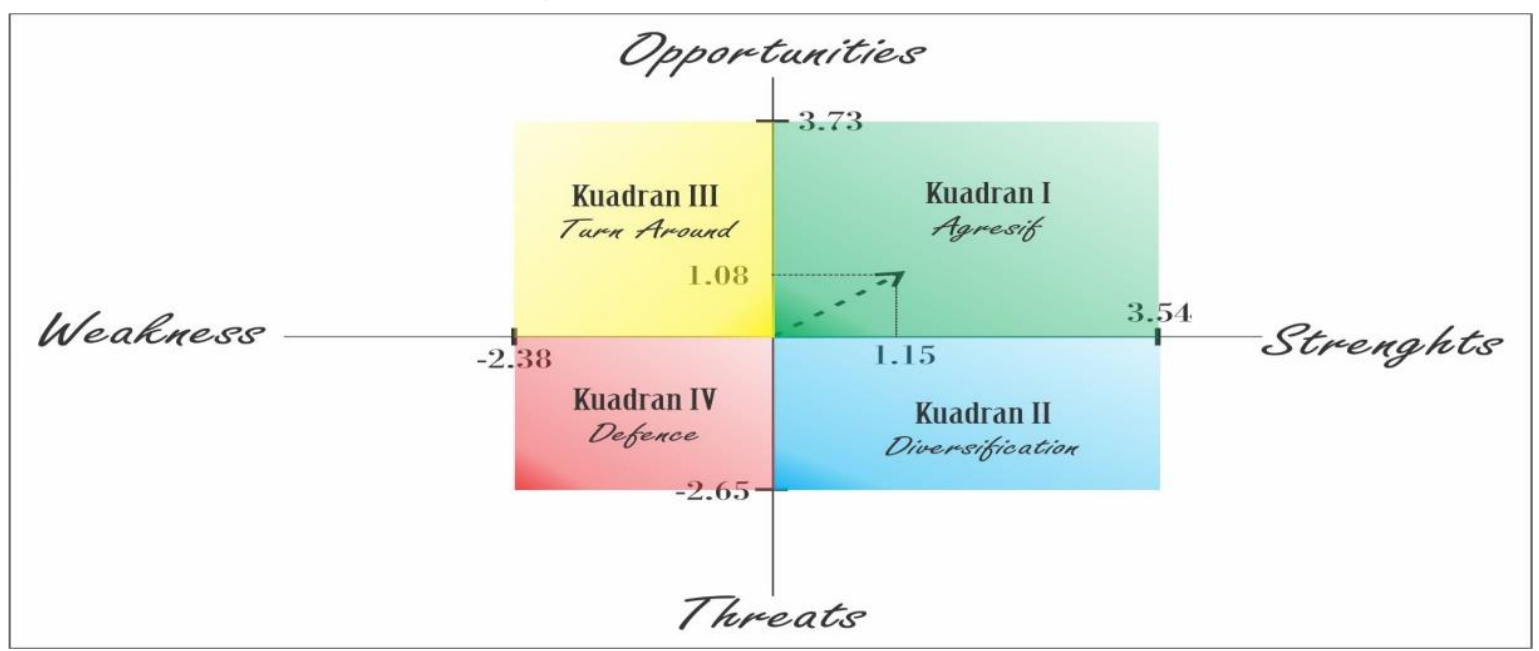

Gambar 1. Diagram SWOT Pencegahan Kebakaran Hutan dan Lahan di Kabupaten Kepuluan Meranti. 
Matrik SWOT menjelaskan secara rinci bagaimana peluang dan ancaman terhadap pencegahan kebakaran hutan dan lahan dapat disesuaikan dengan kekuatan dan kelemahan yang dimilikinya. Matrik SWOT ini menghasilkan empat sel kemungkinan alternatif strategi S-O atau kuadran I yaitu strategi ini merupakan situasi yang sangat menguntungkan dengan memanfaatkan seluruh kekuatan untuk merebut dan memanfaatkan peluang sebesarbesarnya. Starategi yang harus diterapkan dalam kondisi ini adalah mendukung kebijakan yang agresif (growth oriented strategy). Alternatif Strategi (SO). 1) mengangkat kearifan lokal sebagai upaya pencegahan kebakaran hutan dan lahan, 2) menciptakan mitra kerja antara perusahaan dan masyarakat, 3) mengoptimalkan pemanfaatan hasil penelitian dan kajian, 4) mengoptimalkan peran $\mathrm{BRG}, 5)$ meningkatkan koordinasi pemerintah daerah dengan stakeholder terkait, 6) pemanfaatan dukungan internasional ke dalam penanggulangan kebakaran

Penelitian ini menghasilakan suatu model kelembagaan yang berbasis pada kemasyarakatan yang bersinergis antara Pemerintah Daerah Kabupaten Kepuluan Meranti , perguruan tinggi dan Masyarakat Peduli Api (MPA).

\section{PEMBAHASAN}

Masyarakat di Kabupaten Kepuluan Meranti membuka hutan untuk perladangan, perkebunan dan industri. Penggunaan api dalam kegiatan persiapan lahan sebagai sub indikator dari faktor sosial budaya memiliki hubungan dengan penyebab terjadinya kebakaran hutan dan lahan. Deforestasi lahan gambut merupakan salah satu pemicu kebakaran lahan gambut di Indonesia, terutama konversi lahan menjadi perladangan, perkebunan dan industri, hal ini terkait dengan akar penyebab kebakaran lahan gambut di Indonesia, dimana penggunaan api untuk penyiapan lahan (Saharjo, 1999; Chokkalingam dan Suyanto, 2004; Adinugroho et al., 2005; Noor, 2010; KLH, 2010; Wahyunto et al., 2013 ; Wahyunto et al., 2013 ${ }^{\mathrm{b}}$; Masganti et al., 2014 dan Dermawan, 2015). Sesuai dengan hasil penelitian (Bibiana et al., 2010 dan Mark et al., 2010) menyatakan bahwa kebakaran yang terjadi di Tanam Nasional Canaima (CNP),
Venezuela dan Ghana yang dilakukan oleh suku asli/ petani yang menggunakan api dalam penebangan dan pembakaran yang dilakukan dalam pembukaan dan persiapan lahan pertanian/bercocok tanam dan kegiatan berburu.

Dalam kegiatan sehari-hari masyarakat di Kabupaten Kepuluan Meranti, pembalakan liar atau ilegal logging dan perambahan hutan memiliki hubungan dengan penyebab terjadinya kebakaran hutan dan lahan. Sesuai dengan penelitian Syaufina (2008), menjelaskan faktor penyebab kerusakan hutan di Indonesia, diantaranya penebangan liar (illegal logging), alih fungsi hutan serta kebakaran hutan dan lahan. Faktor Kondisi Cuaca dan Iklim/Ekologi yang terdiri dari sub indikator merupakan faktor yang berpengaruh besar penyebab kebakaran hutan dan lahan karena dengan perubahan kondisi cuaca dan iklim yang ekstrim Kabupaten Kepuluan Meranti mengalami kebakaran hutan dan lahan. Tekanan udara udara memiliki hubungan dengan penyebab terjadinya kebakaran hutan dan lahan. Sedangkan di Eropa terutama dicekungan Mediterania sebagian besar kebakaran disebabkan oleh Kondisi cuaca, bahan bakar dan topografi (Gauteume et al., 2013). Curah hujan (presipitasi) memiliki hubungan dengan penyebab terjadinya kebakaran hutan dan lahan. Curah hujan merupakan unsur iklim yang memiliki korelasi yang tinggi terhadap kejadian kebakaran. Curah hujan juga berpengaruh terhadap kelembaban bahan bakar. Jika curah hujan tinggi maka kelembaban bahan bakar akan tinggi sehingga menyulitkan terjadinya kebakaran. Curah hujan merupakan unsur iklim yang mempunyai keragaman tinggi, karena pola hujan bervariasi menurut skala ruang dan waktu (Asdak, 2002 dan Darmawan, 2015).

Faktor ekonomi ada hubungan dengan penyebab terjadinya kebakaran hutan dan lahan. Tetapi secara sub indikator faktor ekonomi tidak memiliki hubungan dengan penyebab terjadinya kebakaran hutan dan lahan. Keadaan ekonomi pada lokasi penelitian di Kabupaten Kepulauan Meranti merupakan daerah kepulauan sebagian besar masyarakat hidup di desa-desa yang berada di pesisir pantai. Kondisi dan situasi membuat masyarakat masih hidup dalam kategori prasejahtera yang tinggi angka kemiskinan dan minimnya lapangan pekerjaan dan usaha serta infrastruktur pedesaan yang 
buruk tetapi kebakaran tetap terjadi di Kabupaten Kepuluan Meranti.

Kebakaran hutan dan lahan memiliki hubungan yang berdampak terhadap terganggunya aktivitas sehari-hari. Dampak kebakaran hutan menyebabkan penurunan jumlah pendapatan yang diperoleh oleh masyarakat lokal untuk memenuhi kebutuhan pokoknya. Kondisi demikian menyebabkan kelangkaan pangan karena kebun sebagai salah satu penghasil pangan telah rusak/hancur. Peristiwa kebakaran hutan dan lahan gambut menimbulkan implikasi sosial/kejiwaan dan ekologi yang serius. Sesuai dengan penelitian (Adinugroho et al., 2005 dan Tacconi et al., 2008) bahwa asap kebakaran hutan dan lahan gambut dapat menjalar sehingga mengganggu sistem transportasi penerbangan, aktivitas ekonomi dan kesehatan masyarakat seperti infeksi saluran pernafasan akut (ISFA), diare dan gatal-gatal (Sumantri, 2003; Aikan, 2004; Hergoualc'h and Verchot, 2013).

Kebakaran hutan dan lahan memiliki hubungan yang berdampak terhadap ancaman abrasi. Sejalan dengan penelitian (Gunawan et al., 2012 dan Hafni, 2015) menyatakan adanya dugaan terjadinya fenomena subsidence (penurunan permukaan lahan gambut), serta minimnya tegakan hutan menyebabkan hembusan angin yang keras langsung berdampak tumbangnya tegakkan hutan-hutan yang tersisa, terutama hutan di zona penyangga dengan topografi yang datar. Perubahan penggunaan lahan ini perlu memperhatikan aspek keseimbangan tata ruang wilayah agar tidak menimbulkan bencana dimasa yang akan datang. Kebakaran hutan dan lahan berdampak pada kualitas air sehingga gambut tidak lagi bisa menyimpan air akibat terjadinya penurunan pemukaan air. Sesuai dengan penelitian (Wosten et al., 1997; Noor, 2010; Rais, 2011) menyatakan sedikitnya cadangan air yang tersimpan selama musim hujan, maka cadangan air yang dapat diterima oleh daerah sekelilingnya menjadi lebih sedikit dan daerah sekitarnya akan rentan kekeringan pada musim kemarau.

Kebakaran hutan dan lahan memiliki hubungan yang berdampak terhadap hilangnya sejumlah mata pencaharian masyarakat di sekitar hutan. Dampak langsung kebakaran lahan gambut bagi manusia adalah kehilangan sumber mata pencaharian masyarakat terutama bagi mereka yang masih menggantungkan hidupnya pada sumber daya alam (berladang, beternak, berburu/menangkap ikan dan sebagainya) (Adinugroho et al., 2005). Kebakaran hutan dan lahan berdampak pada transportasi masyarakat di Kabupaten Kepuluan Meranti. Kehidupan masyarakat sangat tergantung pada transportasi laut/sungai dari pada transportasi darat atau udara dalam melakukan aktivitas sehari-hari di Kabupaten Kepuluan Meranti. Sesuai dengan penelitian yang terdahulu bahwa asap kebakaran hutan dan lahan gambut dapat menjalar sehingga mengganggu sistem transportasi penerbangan, aktivitas ekonomi dan kesehatan masyarakat seperti infeksi saluran pernafasan akut (ISFA), diare dan gatal-gatal (Sumantri, 2003; Aikan, 2004; Hergoualc'h and Verchot, 2013).

\section{Peran Sagu Dalam sosial budaya, ekonomi dan lingkungan}

Sagu di Indonesia tumbuh dalam bentuk hamparan hutan yang kurang terpelihara sebagai mana mestinya. Adapun peran sagu dilihat dari segi aspek ekologi, ekonomi dan soial budaya sebagai berikut :

Tanaman sagu tidak memerlukan teknologi budidaya yang tinggi dan pemeliharaannya ringan dan menampung tenaga kerja. Sejalan dengan penelitian Hariyanto (2011) menyatakan dengan adanya kegiatan pengolahan sagu tersebut akan dapat menampung tenaga kerja dan diharapkan dapat menggerakkan perekonomian yang lain. Hasil penelitian ini sesuai juga dengan penelitian (Rahayu et.al, 2013), menjelaskan bahwa tanaman sagu merupakan ketahanan pangan bagi masyarakat lokal, beranekaaragam dan produktivitas bermasalah dengan habitat. Tanaman sagu di Pulau Padang tumbuh dan berkembang di habitat gambut, habitat kilang manis, habitat bertanah liat dan rawa payau dan sementara habitat tersebut semakin terdesak akibat konversi lahan menjadi macam tujuan contohnya pembangunan pemukiman dan komoditas tanaman perkebunan.

terdapat sumber-sumber air dalam bentuk pancuran dan disekitarnya terdapat tanaman sagu. Kepulauan Meranti 60\% merupakan wilayah gambut. Sejalan juga dengan penelitian Ibrahim et.,al. (2015) menyatakan secara 
ekologis tanaman sagu dapat tumbuh, berkembang dan berproduksi pada lahan marginal yang tanaman lain sulit tumbuh.

\section{Peran Tradisi Bele Kampung Terhadap Aspek Sosial Budaya, Ekologi dan Ekonomi.}

Masyarakat Desa Dedap meyakini adanya nasib dan keterbatasan baik manusia sebagai makhluk sosial maupun lingkungan. Hasil penelitian ini sesuai juga dengan penelitian Tianotak (2010) dan Mulyadi (2013) bahwa pemberdayaan dengan penguatan potensi yang dimiliki oleh masyarakat adat. Oleh sebab itu perlu perlindungan hukum khususnya dalam bentuk peraturan perundang-undangan dari Negara. Jaminan terhadap pelaksanaan fungsi dan peranan masyarakat adat dalam pengelolaan sumber daya hutan akan berdampak positif terhadap kelestariaan lingkungan hidup. Peran serta masyarakat akan menumbuhkan rasa memiliki tanggungjawab terhadap kelestarian lingkungan hidup dengan melakukan reorientasi, gerakan sosial, pengembangan institusi dan kapasitas. Pemerintah dan masyarakat dapat mengambil sikap terhadap program pemberdayaan masyarakat. Gerakan sosial yang dilakukan msyarakat lokal membutuhkan institusi lokal yang berfungsi bukan semata-mata sebagai suatu organisasi, melainkan sebagai pranata social.

Bila melihat kajian sebelumnya maka posisi penelitian ini merupakan penelitian baru. Penelitian cukup baru karena penelitian ini menfokuskan hanya pada pencegahan kebakaran hutan dan lahan yang berbasis pada kelembagaan yang terpadu dan komprehensif yang efektif dan efisien di Kabupaten Kepuluan Meranti Provinsi Riau. Berbeda dengan penelitian yang terdahulu yang memberikan gambaran sekedar penguatan kelembagaan penanggulangan kebakaran hutan dan lahan pada aspek pemadaman dan tidak membahas berbagai aspek seperti seberapa besar pengaruhnya perguruan tinggi dan lembaga masyarakat yang ada pada tiap-tiap desa yang mengalami kebakaran hutan dan lahan. Hasil penelitian Suhendri et al, (2017) menyatakan pencegahan dan pengendalian kebakaran hutan dan lahan di Kabupaten Muaro Jambi belum sampai pada tujuan. Permasalahan yang belum jelasnya tata kelola ruang lahan gambut serta penegakan hukum yang tidak tegas, tidak patuhnya pemerintah daerah dan pemegang izin usaha dalam memberikan pengawasan.

$$
\text { Penelitian Irwandi et al, (2016) }
$$
menjelaskan bahwa kegiatan pengendalian kebakaran hutan di Desa Purwajaya Kecamatan Loa Janan Kabupaten Kutai Kartanegara Kalimantan Timur yang telah dan sedang dilakukan oleh pihak Dinas Kehutanan. Kegiatan penyuluhan yan telah dilakukan oleh Dinas Kehutanan dinilai kurang mendapatkan respon yang baik dari masyarakat sekitar hutan. Penelitian Fera (2016) Kinarja pegawai Badan Penanggulangan Bencana dan Pemadaman kebakaran Kabupaten Pelalawan dalam menangani kasus kebakaran hutan dan lahan yang dilakukan pegawai sudah dilakukan dengan baik. Dalam melakukan pencapaian kinerja pegawai Badan Penanggulangan Bencana dan Pemadaman kebakaran terdapat beberapa factor yang mempengaruhi antara lain: (a) tidak adanya alat ukur standar peningkatan kinerja, (b) tidak adanya pencatatan hasil penilaian kinerja dan (c) masih terdapat pegawai yang kurang memiliki kemampuan kerja. Selanjutnya penelitian Cahyono et al, (2015) Kebijakan pengendalian kebakaran hutan sebaiknya diarahkan pada upaya pencegahan terjadinya hotspot dibandingkan dengan kebijakan saat ini lebih cenderung pada upaya pemadaman kebakaran hutan. Perubahan paradigma pengendalian kebakaran hujtan dan lahan ini perlu didukung dengan sosialisasi, dukungan anggaran, sumberdaya manusia, dan peralatan.

Sedangkan Penelitian Bahri (2002), Upaya untuk mengatasi dan menanggulangi kebakaran hutan dan lahan dapat dikelompokan pada dua cara, Cara pertama pemadaman dari permukaan dan kedua pemadaman dari udara. Penanggulangan cara pertama dilaksanakan oleh instansi yang terkait yaitu departemen Kehutanan dan Pemerintah Daerah. Penanggulangan cara kedua yaitu dari udara dapat dilakukan dengan menerbangkan pesawat pembom air misalnya US-1A. Water Bomber dan pesawat CL-415M. Penelitian Dani et al, (2015) menyatakan bahwa sejauh ini yang dilakukan oleh masyarakat dalam penanggulangan kebakaran hutan dan lahan di Kabupaten Rokan Hilir adalah mengumpulkan masyarakat sekitar lokasi kebakaran. Serta bergotong royong untuk mematikan api 
denganmenggunakan alat-alat sederhana seperti timba,ember dan lain-lain. Hal tersebut dikarenakan selama ini masyarakat belum banyak mengetahui seperti apa keterlibatan yang harus mereka lakukan dalam kebijakankebijakan pemerintah dalam menangani kebakaran.

Selanjutnya Penelitian Fitra (2014) Koordinasi Dinas Kehutanan Kabupaten Rokan Hilir dalam upaya pencegahan kebakaran hutan dan lahan berlangsung baik/berkualitas dapat dilihat dari empat indikator yang digunakan untuk mengukur pelaksanaan koordinasi yaitu: perencanaan, komunikasi, pembagian tugas, dan pengawasan.

Penelitian Destari et al, (2016) menyatakan koordinasi dalam pencegahan kebakaran hutan dan lahan di Kabupaten Kuantan Sengingi belum berjalan dengan lancar baik koordinasi kedalam maupun keluar. Begitu juga dengan koordinasi dalam menyatukan dan menyelaraskan pekerjaan dalam pencegahan kebakaran hutan dan lahan. Penelitian Akbar et al, (2011) menyatakan aktivitas pencegahan kebakaran jika dilakukan melalui kolaborasi antara pemerintah dengan masyarakat sekitar hutan terutama dengan petani lading dan penangkap ikan berpotensi menurunkan frekuensi terjadinya kebakaran. Regu Pengendali Kebakaran (RPK) yang telah dibentuk di desa telah diakui keberadaannya oleh sebagian besar masyarakat sehingga jika difungsikan sebagai lembaga control kebakaran di tingkat desa. Serta penelitian Harun (2016) Adapun instansi yang berperan dalam masalah kebakaran hutan dan lahantersebut adalah sebagai berikut: (1) Badan Penanggulangan Bencana Daerah (BPBD) sebagai coordinator pengendalian kenakaran hutan dan lahan kebakaran hutan dan lahan, (2) Badan Pengendalian Dampak Lingkungan (Bapedal) sebagai penyelenggara fungsi pencegahan dan penanggulangan pencemaran dan/atau kerusakan lingkungan serta pemulihan kualitas lingkungan hidup. (3) Dinas Kehutanan (Dishut) sebagai coordinator penyusunan kebijakan/peraturan daerah yang berhubungan dengan pencegahan dan penanggulangan kebakaran hutan.

\section{SIMPULAN}

Berdasarkan hasil penelitian ini dapat disimpulkan beberapa hal sebagai berikut:

1. Penyebab kebakaran hutan dan lahan di Kabupaten Kepuluan Meranti adalah faktor sosial budaya dan kondisi cuaca dan iklim/ekologi. Sedangkan yang paling dominan penyebab kebakaran hutan dan lahan di Kabupaten Kepuluan Meranti adalah faktor sosial budaya

2. Kebakaran hutan dan lahan di Kabupaten Kepuluan Meranti memiliki dampak terhadap faktor sosial budaya, ekologis dan kerusakan lingkungan serta ekonomi. Sedangkan faktor yang paling besar terkena dampak terjadinya kebakaran hutan dan lahan adalah faktor sosial budaya.

3. Pencegahan kebakaran hutan dan lahan di Kabupaten Kepuluan Meranti dapat dilakukan dengan cara megupayakan kepada masyarakat agar membudayakan dan menanam sagu yang merupakan kearifan lokal dan juga melestarikan tradisi-tradisi yang ada kaitannya dengan lingkungan luas seperti bele kampung.

4. Model pencegahan kebakaran hutan dan lahan yang berbasis pada kelembagaan terpadu antara pemerintah, perguruan tinggi dan lembaga masyarakat menjadi komprehensif yang efektif dan efisen.

\section{UCAPAN TERIMA KASIH}

Ucapan terima kasih penulis sampaikan kepada Bupati Kepuluan Meranti, Kepala Dinas, Kepala Badan, Kepala Desa yang berada di Kabupaten Kepuluan Meranti yang telah memberikan data dan informasi tentang model kelembagaan terpadu pencegahan kebakaran hutan dan lahan serta semua pihak yang telah membantu terlaksananya penelitian ini di lapangan.

\section{DAFTAR PUSTAKA}

Adinugroho, W.C., Suryadiputa, I.N.N., Saharjo, B. H., dan Siboro, L. 2005. Panduan Pengendalian Kebakaran Hutan dan Lahan Gambut Bogor: Wetlands International-IP, ISBN: 979-95899-8-3. 
Aiken, S.R. 2004. Runaway Fires, Smoke-Haze Pollution, and Un-natural Disesters in Indonesia. The Geographical Review 94 (1) : 55-79.

Asdak, C. 2002, Hidrologi Dan Pengelolaan Daerah Aliran Sungai, Gajah Mada. University Press, Yogyakarta.

Creswell, John W. 2010. Research Design, Pendekatan Kualitatif, Kuantitatif, dan Mixed.Yogyakarta:Pustaka Pelajar

Darmawan, B. 2015. Rancangan Bangun Model Pencegahan Kebakaran Ekosistem Hutan Rawa Gambut (Studi Kasus di Kecamatan Teluk Meranti Kabupaten Pelalawan , Provinsi Riau, Disertasi Program Pasca Sarjana Ilmu Lingkungan Universitas Riau, Pekanbaru

Gunawan, H, S. Kobayasi, K. Mizuno, and Y. Kono, 2012. Peat Swamp Forest Types and Their Regeneration in The Giam Siak Kecil-Bukit Batu Biosphere reserve, Riau. Indonesia. Mires and Peat, Vol 10. International Mire Conservation Group and International Peat Sociaty. Helsinki.

Hafni, R. 2015. Analisis Dampak Rehabilitasi Hutan Magrove terhadap Pendapatan Masyarakat Desa Lubuk Kertang Kabupaten Langkat. Jurnal Ekonomi Universitas Muhammadiyah Sumatera Utara. 3 (2).

Hariyanto, B. 2011. Manfaat Tanaman Sagu (Metroxylon sp) Dalam Penyediaan Pangan Dan Dalam Pengendalian Kualitas Lingkungan. Jurnal J. Tek. Ling $12(2)$.

Hergoualc'h,K, and L.V.Verchot, 2013. Greenhouse Gas Emission Factors Land Use and Land-Use Change In Southeast Asian Peatlands. Mitig Adapt Strateg Glob Change 25 (2).

Ibrahim. K., Gunawan, H. 2015. Dampak Kebijakan Konvensi Lahan Sagu Sebagai Upaya Mendukung Pogram Pengembangan Padi Sawah di Kabupaten Halmahera Barat, Maluku Utara. Jurnal PROS SEM NAS MASY BIODIV 1 (5).

Irawan, Prasetya, 2000. Manajemen Sumber Daya Manusia. Jakarta: Sekolah Tinggi Ilmu Administrasi
Jones, D.S. 2006. ASEAN and Transboundry Haze Pollutant in Southeast Asia. Asia Europa Jurnal Volume 4, Issue 3, pp 431-446.

KLH, 2010. Status Lingkungan Hidup. Kementrian Lingkungan Hidup. Jakarta

Litta, H. 2012. Case Study One: TransboundaryHaze Pollutant. Regimes in South Asia. Pp89-138.DOI 10.1007/978-3-531-94276-6_5.

Masganti., Wahyunto., Ai Dariah., Nurhayati., dan Yusuf, R. 2014. Karakteristik dan Potensi Pemanfaatan Lahan Gambut Terdegradasi di Provinsi Riau. J. Sumberdaya Lahan $8: 47-54$.

Mulyadi, M. 2013. Pemberdayaan Masyarakat Adat Dalam Pembangunan Kehutanan (Studi Kasus Komunitas Battang di Kota Palopo, Sulawesi Selatan ). Jurnal Penelitian Sosial dan Ekonomi Kehutanan 10 (4) : 224-234.

Noor, M. 2010. Lahan Gambut, Pengembangan, Konservasi, dan Perubahan Iklim. Gajah Mada University Press. Yogyakarta.

Purnasari, 2011. Strategi Pencegahan Kebakaran Hutan Berbasis Masyarakat (Kajian Biofisik, Ekonomi, Sosial dan Budaya Masyarakat Kawasan Suaka Margasatwa Padang Sugihan Provinsi Sumatera Selatan), Tesis: Universitas Gadjah Mada.

Rahayu et al, 2013. Kesesuaian lahan bekas kebaakaran hutan sebagai upaya konservasi lahan di Gunung Panderman RPH Oro-Oro BKPH Pujon KPH Malang. Gamma, 6(2).

Rais, D. S., 2011. Hidrologi Lahan Gambut dan Peranannya Dalam Kelestarian Lahan Gambut Tropis Indonesia: Prosiding Simposium Nasional Ekohidrologi Jakarta. Wetland International Indonesia Programmme.

Rencana Tata ruang dan Wilayah Kabupaten Kepuluan Meranti, 2011. RTRW Meranti-Bappeda, 2011-2031

Saharjo, B.H.1999. Study of Forest Fire Preventive For Fast Growing Tree Species Acacia Magium Plantation in South Sumatera, Indonesia. Kyoto University, Graduate School of Agriculture. 
Sugiyono. 2011. Metode Penelitian Kuantitatif dan Kualitatif dan R\&D Alfabeta

Sukmadinata, Nana Syaodih. 2008. Metode Penelitian Pendidikan. Bandung: PT. Remaja Rosdakarya

Sumantri, 2003. Prinsip Pencegahan Kebakaran Hutan. IPB Press. Bogor.

Suratmo, F.G., E.A. Husaeni, N. Surati Jaya. 2003. Pengetahuan Dasar Pengendalian Kebakaran Hutan. Pedoman Nasional Pengendalian Kebakaran Hutan. Institute Pertanian Bogor.

Suwondo, Arnel.I, Arneliwati, Isnaini.Z.L, Prayitno.A, Gunawan.H, Arifudin, Susilawati. 2015. Pengelolaan Lingkungan Berkelanjutan: Penguatan Program Pencegahan Kebakaran Hutan dan Lahan (karhutla) Berbasis Masyarakat. UR Press

Syaufina L. 2008. Kebakaran Hutan dan Lahan di Indonesia Perilaku Api, Penyebab, dan Dampak Kebakaran. Malang (ID): Bayumedia.

Tacconi, L., Jotzo, F.,Grafton, F.Q. 2008. Local Causes. Regional Co-opration and Global Financing for Environmental Problems. The Case of Southeast Asian Haze Pollution. Int Environ Agreements (2008) 8:1-16. DOI $10.1007 / \mathrm{s} 10784-$ $007-9057 z$.
Tianotak, N. 2010. Perlindungan Hukum Atas Hak Asasi Masyarakat Adat Dalam Pengelolaan Sumber Daya Hutan di Provinsi Maluku. Jurnal Sasi 16 (4) : Bulan Oktober-Desember 2010

Wahyunto., Ritung, S., Nugroho, K., Sulaiman, Y., Hikmarullah., Tafakresnanto, C., Suparto., dan Sukarman. 2013a. Peta Arahan Lahan Gambut Terdegradasi di Pulau Sumatera Skala 1:250.000 Badan Litbang Pertanian, Kementerian Pertanian . Bogor.

Wahyunto., Ai Dariah., Pitono, D., dan Sarwani, M. 2013b. Prospek Pemanfaatan Lahan Gambut untuk Perkebunan Kelapa Sawit di Indonesia. Perspektif 12 (1) : 11-12.

Wosten, J.H.M., Ismail, A.B., and van Wijk, A.L.M. 1997. Peat Subsidence and Its Practical Implications: A Case Study In Malaysia. Geoderma.

Zubaidah, A., Dirgahayu, D., Sariwulan, B. 2005. Pengaruh Anomali Curah Hujan Terhadap Potensi Kebakaran Hutan /Lahan di Pulau Sumatera Pertemuan Ilmiah Tahunan MAPIN XIV. Jakarta: Lapan 